\title{
Effect of Exogenous Surfactant on the Development of Surfactant Synthesis in Premature Rabbit Lung
}

\author{
MAURIZIO AMATO, KEVIN PETIT, HUMBERTO H. FIORE, CYNTHIA A. DOYLE,
} IVAN D. FRANTZ, III, AND HEBER C. NIELSEN

\author{
Division of Newborn Medicine, The Floating Hospital for Infants and Children at New England Medical \\ Center, Boston, MA 02111, U.S.A. [K.P., H.H.F., C.A.D., I.D.F., H.C.N.], and Department of Medicine, \\ University of Berne, Switzerland [M.A.].
}

ABSTRACT

\begin{abstract}
Surfactant replacement is an effective therapy for neonatal respiratory distress syndrome. Full recovery from respiratory distress syndrome requires development of endogenous surfactant synthesis and metabolism. The influence of exogenous surfactant on the development of surfactant synthesis in premature lungs is not known. We hypothesized that different exogenous surfactants have different effects on the development of endogenous surfactant production in the premature lung. We treated organ cultures of d 25 fetal rabbit lung for $3 \mathrm{~d}$ with $100 \mathrm{mg} / \mathrm{kg}$ body weight of natural rabbit surfactant, Survanta, and Exosurf and measured their effects on the development of surfactant synthesis. Additional experiments tested how these surfactants and Curosurf affected surfactant protein (SP) SP-A, SP-B, and SP-C mRNA expression. Surfactant synthesis was measured as the incorporation of ${ }^{3} \mathrm{H}$-choline and ${ }^{14} \mathrm{C}$-glycerol into disaturated phosphatidylcholine recovered from lamellar bodies. Randomized-block ANOVA showed significant differences among treatments for incorporation of both labels $(p<0.01)$, with natural rabbit surfactant less than control, Survanta greater than control, and Exosurf unchanged. Additional experiments with natural rabbit surfactant alone showed no significant effects in doses up to $1000 \mathrm{mg} / \mathrm{kg}$. Survanta stimulated disaturated phosphatidylcholine synthesis $(173 \pm 41 \%$ of control; $p=0.01)$, increased total
\end{abstract}

lamellar body disaturated phosphatidylcholine by $22 \%$ ( $p<$ $0.05)$, and increased ${ }^{14} \mathrm{C}$-disat-PC specific activity by $35 \%(p<$ 0.05 ). The response to Survanta was dose-dependent up to 1000 $\mathrm{mg} / \mathrm{kg}$. Survanta did not affect surfactant release. No surfactant altered the expression of mRNA for SP-A, SP-B, or SP-C. We conclude that surfactant replacement therapy can enhance the maturation of surfactant synthesis, but this potential benefit differs with different surfactant preparations. (Pediatr Res 53: 671-678, 2003)

\begin{tabular}{l}
\multicolumn{1}{c}{ Abbreviations } \\
DPPC, dipalmitoyl phosphatidylcholine \\
disat-PC, disaturated phosphatidylcholine \\
LB, lamellar body \\
NARS, natural adult rabbit surfactant \\
PC, phosphatidylcholine \\
PG, phosphatidylglycerol \\
PI, phosphatidylinositol \\
RDS, neonatal respiratory distress syndrome \\
SP-A, surfactant protein A \\
SP-B, surfactant protein B \\
SP-C, surfactant protein C
\end{tabular}

The biophysical activity associated with lung surfactant is achieved through the complex interaction of a mixture of phospholipids and SP-A, SP-B, and SP-C (1-4). The lipid and protein surfactant components are produced in lung type II cells and stored in LB as a pool available for secretion. The regulation of surfactant availability is achieved through a cycle of synthesis,

Received July 25, 2002; accepted September 25, 2002.

Correspondence: Heber C. Nielsen, M.D., Division of Newborn Medicine, New England Medical Center, NEMC \#97, 750 Washington Street, Boston, MA 02111, U.S.A.; e-mail: hnielsen@lifespan.org

Supported by NIH grant HL37930, a grant from Chiesi Pharmaceuticals, and reagents from Dey Laboratories and Ross Laboratories.

DOI: 10.1203/01.PDR.0000054655.95452.06 storage, secretion into the alveolar space, reuptake, and recycling of intact phospholipid components. Although the individual function of each surfactant protein has not been completely defined, they are active in the metabolism as well as the function of lung surfactant. Hydrophilic SP-A mediates the endocytosis and reutilization of secreted surfactant components, whereas hydrophobic SP-B and SP-C act together to facilitate the adsorption of surfactant phospholipids to the air-liquid interface (1). SP-B also mediates the processing and assembly of surfactant into the LB structure in type II cells (5). A lung capable of efficient gas exchange must have a surfactant system that can coordinate synthesis, recycling, and degradation of surfactant lipids and surfactant-associated proteins. 
Surfactant replacement therapy is an effective treatment for neonatal RDS (6), although its clinical efficacy is primarily in alleviating, rather than curing, $\operatorname{RDS}(7,8)$. The normal resolution of RDS requires the postnatal development in a premature lung of a fully functioning endogenous surfactant system, yet the influence of exogenous surfactant on the development of the endogenous system in a premature lung is not understood. Concern has been expressed about the potential effects of exogenous surfactant on the maturation or the function of the alveolar type II cell $(9,10)$. One possible limitation to replacement therapy may involve an interaction between the metabolism of exogenous surfactant and the postnatal development of endogenous synthesis and secretion of pulmonary surfactant in the immature lung. Moreover, any effect on the development of the endogenous surfactant system may vary among different types of surfactant preparations. The commercial surfactant preparations are biochemically diverse and include protein-free "synthetic" surfactants and animal-derived "artificial" surfactants that contain lung-derived surfactant phospholipids together with the hydrophobic surfactantassociated proteins SP-B and SP-C, plus variable amounts of supplemented phospholipid. The artificial surfactant preparations are derived from adult animals with a surfactant system more attuned to degrading surfactant than recycling. Newborn infants recycle $90 \%$ of the alveolar pool of surfactant (11). In adults, alveolar surfactant is mainly cleared and metabolized rather than recycled (12).

We hypothesized that exogenous surfactant would affect the development of endogenous surfactant production in the premature lung, and further that the effect would differ with different types of exogenous surfactant. We tested this hypothesis using premature rabbit lung organ cultures, a model that exhibits development of surfactant synthesis over time similar to in vivo development. We used the model to specifically examine the effect of different surfactant preparations on the development of surfactant phospholipid synthesis and surfactant protein mRNA expression.

\section{METHODS}

Surfactant preparations. Four biochemically diverse surfactant preparations were used. Studies of the effects of exogenous surfactant on surfactant phospholipid production focused on three surfactants, namely NARS, Exosurf, and Survanta. NARS, a natural surfactant isolated from lung lavage of adult rabbits by sucrose gradient centrifugation, was produced in our laboratory as described by Jacobs and Jobe (13). It had a phospholipid concentration of $8.2 \mathrm{mg} / \mathrm{mL}$, of which $86.5 \%$ was PC and $6.1 \%$ was PG. Disat-PC represented $69 \%$ of the total PC. The protein concentration was $1.6 \mathrm{mg} / \mathrm{mL}$. NARS contains all three surfactant proteins. Exosurf (Burroughs-Wellcome, Research Triangle Park, NC, U.S.A.) is a synthetic surfactant consisting of DPPC, hexadecanol, and tyloxapol. It contains no protein. By the manufacturer's specification the concentration of phospholipids is $10.8 \mathrm{mg} / \mathrm{mL}$. It is provided as a lyophilized powder, which was reconstituted with sterile saline according to the manufacturer's instruction. Survanta (Ross Laboratories, Columbus, OH, U.S.A.) is an artificial surfactant (modified natural surfactant) prepared by isolating surfactant isolated from minced bovine lungs and supplementing this with additional DPPC, tripalmitin, and palmitic acid. By the manufacturer's specifications the phospholipid concentration is $25 \mathrm{mg} /$ $\mathrm{mL}$, consisting of $44-62 \%$ DPPC, triglycerides $(0.5-1.75$ $\mathrm{mg} / \mathrm{mL}$ ), and FFA $(1.4-3.5 \mathrm{mg} / \mathrm{mL})$. Survanta also contains the hydrophobic surfactant proteins SP-B and SP-C $(<1 \mathrm{mg} /$ $\mathrm{mL}$ ); the concentration of SP-B is $<10 \%$ of that in native surfactant. Survanta is provided as a suspension in sterile saline. In studies of the development of surfactant protein mRNA expression we used the above three surfactants plus Curosurf (Dey Laboratories, Inc., Napa, CA, U.S.A.) to have a surfactant with a different method of production, a different lipid profile, and surfactant proteins of a different animal species than Survanta. Curosurf is an artificial surfactant produced by organic extraction from minced porcine lungs. By the manufacturer's specifications Curosurf contains 99\% polar lipids, mainly phospholipids, at a concentration of $80 \mathrm{mg} / \mathrm{mL}$, and $1 \%$ hydrophobic surfactant proteins (SP-B and SP-C) in the approximate molar ratio 1:2. Curosurf is provided as a suspension in sterile saline.

Preparation of lung organ cultures. The animal research protocol was approved by the Institutional Animal Care and Use Committee. Timed pregnant New Zealand White rabbits were obtained from Pine Acres Rabbitry (Brattleboro, VT, U.S.A.). In each experiment, four does were killed on gestational d 25 (day of breeding being d 0 and term being d 31). Fetuses were removed from the uterus by hysterotomy and weighed, and the lungs were dissected free under sterile conditions. The lungs were pooled in preweighed Petri dishes. Fetal rabbit lung organ cultures were prepared as we have previously reported (14) with modifications. Pooled lungs were minced, placed onto autoclaved Millipore filters (Type AABP, $0.8 \mu \mathrm{M}$ pore size; Bedford, MA, U.S.A.) supported by metal grids to the air-liquid interface in 10-cm Petri dishes, and cultured in $8 \mathrm{~mL}$ of Weymouth's medium containing $10 \%$ FCS. The amount of lung in each culture was weighed, and this weight used to calculate the fetal body weight equivalent.

Study of de novo surfactant phospholipid synthesis. In each experiment pooled tissue was divided among each of four culture conditions: 1) control (no added surfactant); 2) added NARS (100 mg phospholipid per kilogram fetal body weight equivalent; 3) added Exosurf (100 mg phospholipid per kilogram fetal body weight equivalent); and 4) added Survanta (100 mg phospholipid per kilogram fetal body weight equivalent). These doses were determined on the basis of the dose of surfactant used clinically to treat infants. Similar doses have been used by others in studies of surfactant metabolism and surfactant replacement in whole animal models $(10,15,16)$. Additional studies to evaluate dose responsiveness used doses of $0-1000 \mathrm{mg}$ phospholipid per kilogram fetal body weight equivalent. Media and surfactants were changed daily. Twentyfour hours before harvesting, cultures were treated with either ${ }^{3} \mathrm{H}$-choline $(10$ or $20 \mu \mathrm{Ci}$, specific activity $83 \mathrm{Ci} / \mathrm{mmol}$; Amersham Life Science, Arlington Heights, IL, U.S.A.) or ${ }^{14} \mathrm{C}$ glycerol $(20 \mu \mathrm{Ci}$, specific activity $100 \mathrm{mCi} / \mathrm{mmol}$; ICN Pharmaceuticals, Irvine, CA, U.S.A.). After $24 \mathrm{~h}$ the tissue was harvested and the LB fraction isolated. In one group of studies 
both ${ }^{14} \mathrm{C}$-glycerol and ${ }^{3} \mathrm{H}$-choline were added together to evaluate the relationship of choline and glycerol incorporation into disat-PC. After initial experiments to test all four conditions, only NARS and control, or only Survanta and control conditions were performed to further evaluate the effects of these surfactants on the development of fetal lung surfactant synthesis.

$L B$ isolation and measurement of disat-PC and PC. After $24 \mathrm{~h}$ of incubation with the radiolabeled choline or glycerol, cultures were harvested, and the tissue was weighed and homogenized in Tris-EGTA buffer. Aliquots from homogenates were taken for protein determination (17). LB were then isolated from the remaining homogenates by serial density centrifugation as we have described (18). We have previously documented a $54 \%$ efficiency in LB recovery (14). The resulting LB pellet was stored at $-70^{\circ} \mathrm{C}$ until subsequent phospholipid assay. Phospholipids were extracted from the LB, and LB disat-PC was isolated by thin-layer chromatography $(14,18)$. The incorporation of ${ }^{3} \mathrm{H}$-choline or ${ }^{14} \mathrm{C}$-glycerol into LB disat-PC was measured by scintillation counting. Total disat-PC was determined by phosphorus assay (19).

Disat-PC uptake. The effect of exogenous surfactant disat-PC uptake was evaluated by measuring the uptake of ${ }^{3} \mathrm{H}$-disat-PC $(5 \mu \mathrm{Ci}$, specific activity $40 \mathrm{Ci} / \mathrm{mmol}$; Dupont, Wilmington, DE, U.S.A.) added to both control and Survantatreated cultures for either 1,2 , or $3 \mathrm{~d}$. At the end of this time aliquots of tissue were used for lipid extraction followed by isolation of total disat-PC and for total protein measurement. The remaining tissue was used to evaluate LB disat-PC. Tissue and surfactant $\mathrm{LB}{ }^{3} \mathrm{H}$-disat-PC was measured by scintillation counting.

Surfactant secretion. Cultures were prepared and treated with surfactants as described above. After $3 \mathrm{~d}$ in culture, the tissue was washed twice with fresh medium, then cultured for an additional $24 \mathrm{~h}$ in medium alone (no exogenous surfactant) plus ${ }^{3} \mathrm{H}$-choline and ${ }^{14} \mathrm{C}$-glycerol. After this additional $24-\mathrm{h}$ culture period, both the medium and tissue were collected. LB were isolated from the tissue, and disat-PC was extracted as described above. Phospholipids were also extracted from the media, and disat-PC was isolated (20). The incorporation of the two radiolabels into disat-PC in the medium and tissue was measured by scintillation counting. In one experiment, surfactant was added after washing and replacing the medium.

Surfactant protein $\boldsymbol{m R N A}$. The effect of surfactant treatment on the development of surfactant protein mRNA expression was studied in a separate group of experiments. The experimental design was as above except that the surfactants studied were 1) control (no added surfactant); 2) added Curosurf; 3) added Exosurf; and 4) added Survanta. All surfactant doses were $100 \mathrm{mg}$ phospholipid per kilogram fetal body weight equivalent. Media and surfactants were changed daily for $3 \mathrm{~d}$, after which the tissue was harvested and total RNA isolated. Tissue wet to dry weight ratios were measured using aliquots from each condition in three experiments as an index of tissue growth during the culture period.

Northern blot analysis. Total RNA was isolated using Trizol reagent (Life Technologies, TECH-Line, Gaithersburg, MD, U.S.A.) according to the manufacturer's instructions. The resulting RNA pellet was air-dried, resuspended in diethylpyrocarbonate-treated water, and stored at $-70^{\circ} \mathrm{C}$. RNA amount was measured by spectrophotometry. The RNA isolation method routinely yielded approximately $300 \mu \mathrm{g}$ of total RNA per $100 \mathrm{mg}$ of tissue. Each Northern blot was prepared using RNA isolated from the four conditions within an individual experiment. This allowed a specific comparison of treatments to their intra-experimental untreated control. Total RNA $(5 \mu \mathrm{g})$ from each sample was separated by electrophoresis on a 1.0\% agarose $-15 \%$ formaldehyde gel. RNA quality was assessed by the integrity of the ribosomal bands after ethidium bromide staining. RNA was then transferred to a Gene Screen Plus Membrane (Dupont, Boston, MA, U.S.A.) by capillary action using $10 \times \mathrm{SSC}(1 \times \mathrm{SSC}: 0.15 \mathrm{M} \mathrm{NaCl}$ and $15 \mathrm{mM}$ trisodium citrate). Membranes were baked at $90^{\circ} \mathrm{C}$ for $2-3 \mathrm{~h}$. Northern blots were prehybridized in $50 \%$ formamide, $10 \%$ dextran sulfate, $1 \mathrm{M} \mathrm{NaCl}, 1 \%$ SDS, $100 \mathrm{mg} / \mathrm{mL}$ salmon sperm DNA (Sigma Chemical Co., St. Louis, MO, U.S.A.) at $42^{\circ} \mathrm{C}$ for $2 \mathrm{~h}$. cDNA probes for SP-A (mouse sequence), SP-B (rat sequence), and SP-C (rat sequence) were previously cloned in our laboratory and their identity demonstrated by restriction analysis and DNA sequencing (21). The probes were radiolabeled via random priming using the Ready To Go kit (Pharmacia Biotech, Piscataway, NJ, U.S.A.). Membranes were then hybridized in the same prehybridization solution with the ${ }^{32}$ P-labeled cDNA probes for SP-A, SP-B, or SP-C (specific activity of $10^{8}-10^{9} \mathrm{cpm} / \mathrm{mL}$ ) at $42^{\circ} \mathrm{C}$ for $16-18 \mathrm{~h}$. After hybridization, Northern blots were washed with $2 \times$ SSC twice for $15 \mathrm{~min}$ at room temperature, $2 \times \mathrm{SSC}$ and $1 \% \mathrm{SDS}$ at $45^{\circ} \mathrm{C}$ twice for $30 \mathrm{~min}$, and $0.1 \times \mathrm{SSC}$ and $0.2 \% \mathrm{SDS}$ at room temperature twice for $30 \mathrm{~min}$. Membranes were then exposed to a phosphorimage screen overnight. Membranes were subsequently stripped and reprobed with a ${ }^{32} \mathrm{P}$-labeled cDNA probe for ribosomal protein L32 as an internal standard (provided by Dr. Michael Shen, Harvard University) (22).

Statistical analysis. Data from experiments with multiple treatments were analyzed by randomized-block ANOVA or, when expressed as percent of control, by ANOVA. Student's $t$ test for paired observations was used in experiments that had only two conditions. Significance was accepted at $p<0.05$ (23).

\section{RESULTS}

Surfactant treatment did not affect fetal lung organ culture tissue health as judged by tissue color and cohesiveness throughout the culture period. Surfactant treatment had no adverse effect on tissue growth as assessed by wet to dry weight ratios measured at the completion of culture and by the change in dry weight from the onset to the conclusion of culture. The wet to dry weight ratios after $3 \mathrm{~d}$ of culture were control, $1.29 \pm 0.16$; Curosurf, $1.24 \pm 0.15$; Exosurf, $1.28 \pm$ 0.11 ; and Survanta, $1.29 \pm 0.14$ (mean $\pm \mathrm{SD} ; n=3-4$ observations each). The overall average increase in dry weight from the beginning to the end of the culture period was $89 \pm$ $15 \mathrm{mg}$ (mean $\pm \mathrm{SEM} ; n=15$ cultures).

The cultures took up the tracer ${ }^{3} \mathrm{H}$-disat-PC into tissue and LB. No differences were found in tissue tracer content between 
control and surfactant-treated cultures, and the data were therefore combined for presentation (Fig. 1). The accumulation in tissue increased with time in culture up to $3 \mathrm{~d}$, although the trend was not significant. The amount of tracer ${ }^{3} \mathrm{H}$-disat-PC in LB appeared stable during this time. The efficiency of intact LB recovery increases with development (Nielsen, unpublished data), suggesting more efficient recovery after $3 \mathrm{~d}$ of culture. This limits the ability to estimate the total tracer ${ }^{3} \mathrm{H}$-disat-PC that was taken up into LB. However, we interpret these results in tissue and LB tracer ${ }^{3} \mathrm{H}$-disat-PC content to indicate the development of a steady-state of tracer turnover. These data suggest that the exogenous surfactant entered the expected recycling pathway.

The mean incorporation of choline and glycerol into LB disat-PC differed among the control and the three surfactant preparations (Table 1; randomized-block ANOVA $p=0.01$ for ${ }^{3} \mathrm{H}$-choline and $p<0.005$ for ${ }^{14} \mathrm{C}$-glycerol). Survanta caused similar increases in choline and glycerol incorporation over control, and cultures treated with NARS showed equivalent reductions in choline and glycerol incorporation. The results for Exosurf-treated cultures were similar to controls. All three surfactant treatments had modestly higher total LB disat-PC compared with the controls; however, these differences were not significant by ANOVA (data not shown). The specific activity of radiolabeled disat-PC was also significantly different among the four cultures conditions for both radiolabels ( $p$ $<0.001$; Table 1). Survanta-treated cultures had the highest incorporation of choline and glycerol per microgram of LB disat-PC, NARS-treated cultures had the lowest, and again

\section{${ }^{3} \mathrm{H}$-Disat-PC Uptake into Tissue and Lamellar Body DSPC}

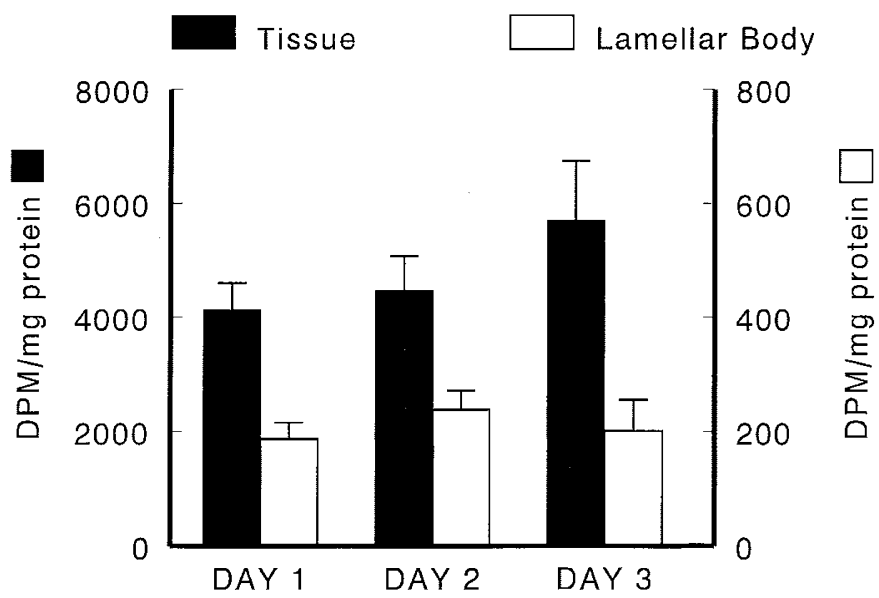

Figure 1. Uptake of tracer ${ }^{3} \mathrm{H}$-disat-PC into tissue and LB disat-PC pools. Organ cultures were incubated with Survanta plus added ${ }^{3} \mathrm{H}$-disat-PC for 1, 2, and $3 \mathrm{~d}$. Total disat-PC was isolated from tissue homogenates and from LB fractions, and the presence of tracer ${ }^{3} \mathrm{H}$-disat-PC was measured by scintillation counting. The data are presented as the mean \pm SEM of six experiments, in disintegrations per minute per milligram of tissue culture protein. Closed bars represent tissue, and open bars LB fractions. ${ }^{3} \mathrm{H}$-disat-PC entered both the tissue and LB pool within $1 \mathrm{~d}$ and remained present in constant amounts throughout the $3 \mathrm{~d}$, suggesting the attainment of a steady-state of ${ }^{3} \mathrm{H}$-disat-PC turnover.
Exosurf was similar to control. All subsequent experiments evaluated an individual treatment (NARS or Survanta) versus control.

Because glycerol and choline are used at different points in the disat-PC synthesis pathway we studied whether surfactant treatment had a differential effect on glycerol incorporation and choline incorporation by including both labels in cultures. A close linear relationship of incorporation of these two labels was found (Fig. 2). These data indicate that effects of surfactant treatment noted for one precursor occur also with the other precursor. In subsequent studies, the effect of NARS was further studied using ${ }^{3} \mathrm{H}$-choline incorporation, and the effect of Survanta further studied using either ${ }^{14} \mathrm{C}$-glycerol and ${ }^{3} \mathrm{H}$ choline incorporation.

The effect of NARS on the development of endogenous surfactant synthesis with time was studied in cultures treated for 3 and $5 \mathrm{~d}$. At d 3, NARS-treated cultures incorporated less radiolabel than controls; however, this was not statistically significant $(58 \pm 10 \%$ of control, mean \pm SEM, $n=7, p=$ 0.11 ). After $5 \mathrm{~d}$ of culture, control and NARS-treated cultures showed almost identical incorporation values, which were 53\% higher than the $\mathrm{d} 3$ controls. We tested for a dose-dependent response to NARS by treating cultures for $3 \mathrm{~d}$ with either 10 , 100 , or $1000 \mathrm{mg} / \mathrm{kg}$. There was no effect of treatment dose on the incorporation of the radiolabeled precursor into disat-PC or on the total surfactant pool size, measured as total LB disat-PC content (data not shown).

In contrast, Survanta treatment had a striking stimulatory effect on endogenous surfactant synthesis. In studies involving just Survanta treatment and controls, glycerol incorporation into LB disat-PC (Fig. 3) was increased by $78 \%$ over controls $(256 \pm 60 \mathrm{dpm} / \mathrm{mg}$ protein versus $146 \pm 21 \mathrm{dpm} / \mathrm{mg}$ protein; mean $\pm \mathrm{SD} ; p=0.01)$. Total LB disat-PC, reflecting surfactant pool size, was $22 \%$ higher in Survanta-treated cultures $(4.52 \pm 0.36 \mu \mathrm{g} \mathrm{P} / \mathrm{mg}$ protein versus $3.67 \pm 0.50 \mu \mathrm{g} \mathrm{P} / \mathrm{mg}$ protein; mean $\pm \mathrm{SD} ; p<0.05)$. The specific activity of glycerol incorporation (expressed per microgram of disat-PC) was also significantly increased in Survanta-treated cultures $(135 \pm 19 \%$ of control, $p<0.05)$, indicating that the effect on endogenous surfactant synthesis was greater than the effect on total pool size. The stimulatory response to Survanta was dose-dependent (Fig. 4). ${ }^{14} \mathrm{C}$-glycerol incorporation increased significantly with increasing Survanta dose $(p<0.01$, ANOVA). Similarly, total LB disat-PC increased significantly with increasing Survanta doses $(p<0.01$, ANOVA; data not shown).

The increase in ${ }^{3} \mathrm{H}$-disat-PC in the LB of Survanta-treated lungs might occur if Survanta prevented the baseline release of LB into the media. To address whether surfactant treatment affected the steady-state secretion of surfactant, we measured ${ }^{3} \mathrm{H}$-choline labeling of LB disat-PC, medium disat-PC, and tissue disat-PC for a $24-\mathrm{h}$ period. Secretion during $24 \mathrm{~h}$, expressed as the percent of ${ }^{3} \mathrm{H}$-disat-PC in the culture media compared with that in LB, was not significantly affected by surfactant treatment (control, $3.1 \pm 0.8 \%$; Survanta, $3.3 \pm$ $0.5 \%$; Exosurf, $3.3 \pm 0.9 \%$; NARS, $5.2 \%$; mean \pm SEM; $n=$ 3 except NARS $n=1$ ). To confirm that the culture media disat-PC reflected surfactant release rather than tissue break- 
Table 1. Effects of three surfactant preparations on the incorporation of ${ }^{3} \mathrm{H}$-choline and ${ }^{14} \mathrm{C}$-glycerol into disat-PC in fetal rabbit lung organ culture

\begin{tabular}{|c|c|c|c|c|c|c|c|c|}
\hline & \multicolumn{2}{|c|}{$\begin{array}{c}{ }^{3} \mathrm{H} \text {-choline incorporation into } \\
\text { disat-PC }\end{array}$} & \multicolumn{2}{|c|}{$\begin{array}{l}\text { Specific activity of }{ }^{3} \mathrm{H} \text {-choline } \\
\text { incorporation }\end{array}$} & \multicolumn{2}{|c|}{$\begin{array}{c}{ }^{14} \mathrm{C} \text {-glycerol incorporation into } \\
\text { disat-PC }\end{array}$} & \multicolumn{2}{|c|}{$\begin{array}{c}\text { Specific activity of }{ }^{14} \mathrm{C} \text {-glycerol } \\
\text { incorporation }\end{array}$} \\
\hline & $\mathrm{dpm} / \mathrm{mg}$ protein & $\%$ control & dpm/g phosphorus & $\%$ control & $\mathrm{dpm} / \mathrm{mg}$ protein & $\%$ control & dpm/g phosphorus & $\%$ control \\
\hline NARS & $533 \pm 131$ & $74 \pm 2$ & $330 \pm 76$ & $69 \pm 10$ & $54.0 \pm 14.2$ & $73 \pm 10$ & $33.7 \pm 7.9$ & $70 \pm 13$ \\
\hline Exosurf & $951 \pm 214$ & $107 \pm 11$ & $488 \pm 53$ & $104 \pm 8$ & $90.0 \pm 16.2$ & $104 \pm 12$ & $47.1 \pm 3.7$ & $101 \pm 8$ \\
\hline Survanta & $1318 \pm 362$ & $140 \pm 15^{*}$ & $539 \pm 51$ & $114 \pm 7$ & $121.4 \pm 28.4$ & $134 \pm 13 \dagger$ & $53.3 \pm 4.1$ & $113 \pm 7$ \\
\hline
\end{tabular}

Data are mean \pm SEM. $n=8$ except for NARS, $n=5 . * p<0.05,{ }^{3} \mathrm{H}$-choline incorporation. $\dagger p<0.01,{ }^{14} \mathrm{C}$-glycerol incorporation; randomized-block ANOVA.

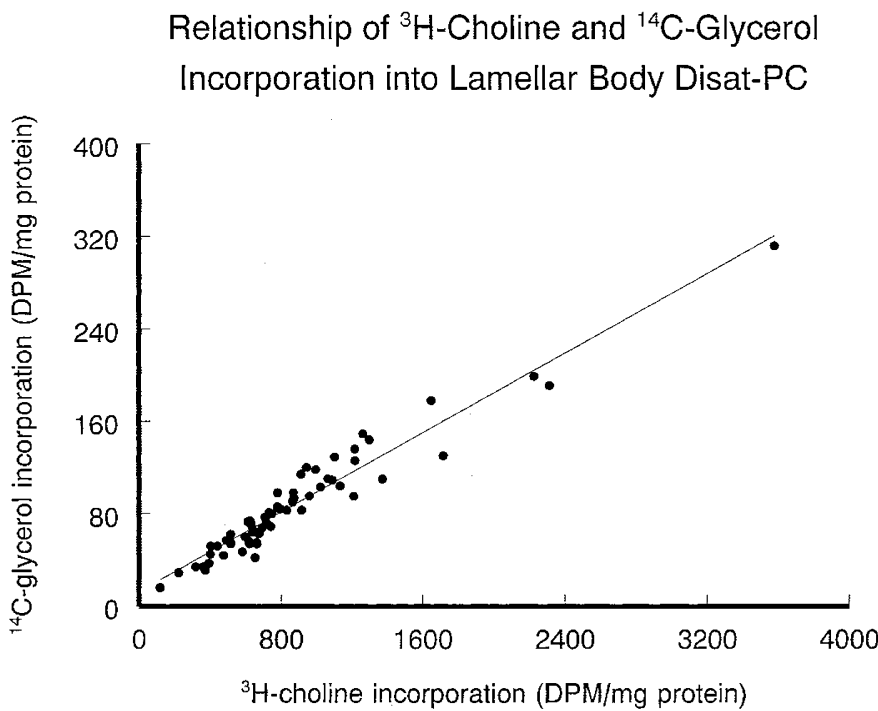

Figure 2. Relationship of ${ }^{3} \mathrm{H}$-choline incorporation and ${ }^{14} \mathrm{C}$-glycerol incorporation into LB disat-PC. Both ${ }^{3} \mathrm{H}$-choline and ${ }^{14} \mathrm{C}$-glycerol were added to cultures treated with either NARS, Survanta, or Exosurf, and untreated controls in a block design. $\mathrm{LB}$ disat-PC was isolated, and ${ }^{3} \mathrm{H}$-disat-PC and ${ }^{14} \mathrm{C}$-disat-PC were measured by scintillation counting and expressed as disintegrations per minute per milligram of tissue protein. A close linear relationship $(y=0.086 x$ $+12.61)$ between the incorporation of the two labels was noted $\left(r^{2}=0.93\right)$.

down, we further measured the proportion of labeled disat-PC compared with labeled $\mathrm{PC}$ in the tissue and the media. The labeled disat-PC represented $59 \%$ of the total labeled PC in tissue and $66 \%$ in the media, suggesting relative enrichment of the media PC pool with disat-PC, consistent with surfactant secretion providing a major amount of disat-PC in the medium. In additional experiments using ${ }^{14} \mathrm{C}$-glycerol as the precursor the ratio of labeled PG to PI was measured. The PG/PI ratio was 1.5 in media and 0.4 in tissue, again indicative that the media pool was relatively enriched with surfactant phospholipids as opposed to tissue phospholipids. Thus, addition of surfactant at the time of adding the radiolabel did not influence surfactant release into the medium.

The effect of a 72-h exposure to Survanta, Exosurf, or Curosurf on expression of SP-A, SP-B, and SP-C was studied in a block design. The cDNA probes for SP-A, SP-B, and SP-C identified one mRNA species for each at molecular sizes of 1.6 $\mathrm{kb}, 1.9 \mathrm{~kb}$, and $0.9 \mathrm{~kb}$, respectively. These sizes are similar to ones previously reported for fetal rabbit surfactant protein mRNAs (24). Representative Northern blots of SP-A, SP-B, and SP-C are shown in Figure 5. Ratios of surfactant protein

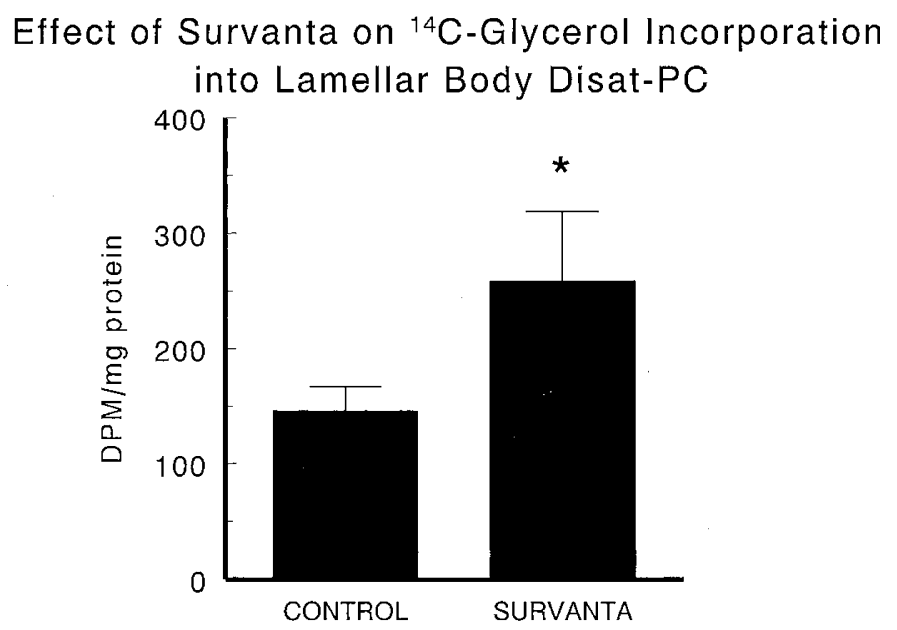

Figure 3. Effect of Survanta on the incorporation of ${ }^{14} \mathrm{C}$-glycerol into LB disat-PC. Cultures were maintained with Survanta for $3 \mathrm{~d}$, with ${ }^{14} \mathrm{C}$-glycerol added for the last $24 \mathrm{~h}$ of culture. Open bars represent control cultures, closed bars represent Survanta-treated cultures. Data are the mean \pm SEM of LB ${ }^{14} \mathrm{C}$-disat-PC, from $n=11$ experiments. *Survanta-treated cultures significantly greater than control, $p=0.01$.

mRNA to ribosomal protein L32 mRNA were computed to correct for possible loading artifact. Because each blot contained RNA from the four conditions within an individual experiment, the ratios for control cultures in each blot were arbitrarily set to 1.0 and ratios for the three surfactant-treated samples were then normalized to their intra-experimental control. The amount of SP-A, SP-B, or SP-C mRNA was not affected by Curosurf, Exosurf, or Survanta (Table 2).

\section{DISCUSSION}

The acute effect of exogenous surfactant administration on endogenous surfactant phospholipid metabolism has been examined in several studies, using a variety of in vitro and in vivo models. The in vitro studies generally used cultured adult type II cells exposed to exogenous surfactant, and have been conflicting and of difficult interpretation. Some studies showed inhibition of endogenous phospholipid synthesis or secretion or both (25-28). Studies also differed regarding whether inhibition was caused by the surfactant lipid fraction, the protein fraction, or both. Conversely, in other studies adult type II cells exhibited significant increases in LB size $(29,30)$, LB number (31) or PC synthesis (30) after exogenous surfactant administration. Additionally, specific surfactant components found to 


\section{Dose-Response Effect of Survanta on ${ }^{14} \mathrm{C}$-Glycerol Incorporation}

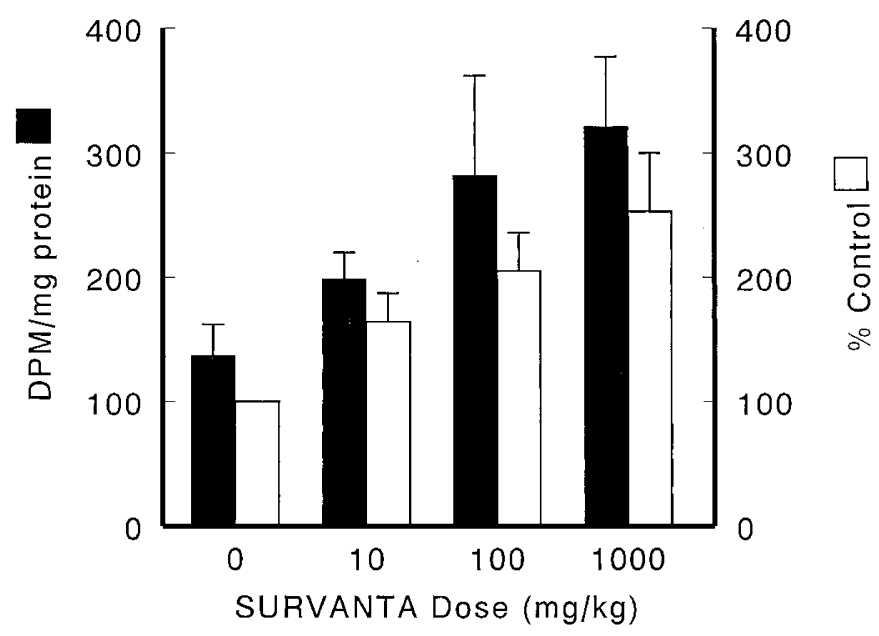

Figure 4. Dose-response effect of Survanta on ${ }^{14} \mathrm{C}$-glycerol incorporation into disat-PC from LB. Cultures were maintained in the indicated doses of Survanta, based on fetal body weight equivalents, for $3 \mathrm{~d}$. LB ${ }^{14} \mathrm{C}$-disat-PC was expressed both as per milligram tissue protein (solid bars) and as percent of control cultures (open bars). Data are the mean \pm SEM of $n=8$ experiments. A significant dose-response relationship of Survanta treatment on $\mathrm{LB}{ }^{14} \mathrm{C}$ disat-PC was seen ( $p<0.01$, ANOVA).

Expression of Surfactant Protein mRNA's from Day 25 Fetal Rabbit Lung Organ Cultures Treated with Exogenous Surfactant

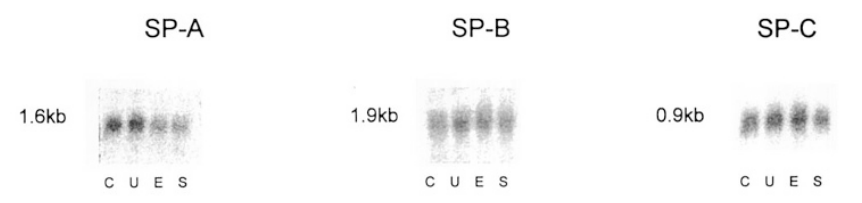

Ribosomal Protein L32 mRNA
$0.65 \mathrm{~kb}$

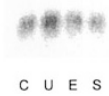

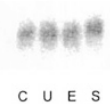

C U E S

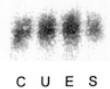

Figure 5. Representative Northern blots of SP-A, SP-B, and SP-C, and the internal standard L32. $C$, control condition; $U$, Curosurf treatment; $E$, Exosurf treatment; $S$, Survanta treatment. The sizes of the detected bands are indicated.

be inhibitory in some studies (27) were stimulatory in others (30).

The acute effects of surfactant treatment on surfactant synthesis have also been addressed using in vivo models of adult, term neonatal, and preterm neonatal animals. Studies conducted in adult or term neonatal sheep or rabbit models generally found little or no effects of exogenous surfactant on the acute synthesis or secretion for times up to $36 \mathrm{~h}$ after a single dose (32-34). A few studies have addressed the acute effects of exogenous surfactant on preterm lungs. Natural sheep surfactant given to preterm newborn lambs had no acute effect on SP-A, SP-B, and SP-C mRNA (35). In mechanically ventilated rabbit pups of $27 \mathrm{~d}$ gestation, administration of natural rabbit
Table 2. Effects of three surfactant preparations on surfactant protein $m R N A$ levels in fetal rabbit lung organ culture

\begin{tabular}{lccc}
\hline & $S P-A$ & $S P-B$ & $S P-C$ \\
\hline Curosurf & $0.90 \pm 0.04$ & $0.77 \pm 0.20$ & $1.02 \pm 0.17$ \\
Exosurf & $0.92 \pm 0.14$ & $0.95 \pm 0.16$ & $0.91 \pm 0.14$ \\
Survanta & $1.03 \pm 0.19$ & $0.99 \pm 0.23$ & $1.06 \pm 0.14$ \\
\hline
\end{tabular}

Data are mean \pm SEM of ratios of surfactant protein mRNA to L32 mRNA. The ratio of the control condition was normalized to 1 for each blot, and the treatment ratios expressed relative to the control. No surfactant treatment significantly affected the expression of any surfactant protein mRNA. $n=3-4$ separate experiments.

surfactant had no effect on the incorporation of either palmitate or glycerol into PC during the first $2 \mathrm{~h}$ of life (36). In mechanically ventilated lambs of $132 \mathrm{~d}$ gestation neither natural sheep surfactant nor surfactant TA affected the incorporation of precursor into surfactant phospholipid in the first $5 \mathrm{~h}$ of life (37). These last two studies were marked by physiologic instability that may have masked potential effects of surfactant.

Of importance, none of these studies addressed the effects of surfactant replacement therapy on the development of surfactant synthesis in the preterm lung. We addressed this question using organ cultures of premature fetal rabbit lungs, a model in which lung maturation progresses similarly to in vivo $(14,38$, 39). We examined how exposure to exogenous surfactant affects the development of surfactant phospholipid synthesis and surfactant protein mRNA levels. The fine mincing of tissue in this model ( $<1$-mm cubes) appears to create a large potential surface area for type II cell exposure to media components, a feature successfully used by others to specifically target treatments to the developing type II cell (40). It is possible that in vivo a larger population of type II cells would be exposed to the surfactant treatments; this would possibly enhance the effects observed here. However, such experiments in an intact model of developing premature lung would be extremely difficult to perform. This model also has the advantage of allowing the recovery of LB so that surfactant phospholipid can be specifically studied, and also avoids potentially confounding variables related to physiologic instability of preterm whole animal preparations. Gestational d 25 rabbits were used in all of these studies because the degree of lung maturation (in terms of surfactant production) is similar to that of the more immature neonates currently treated in intensive care units $(41,42)$. During the 3-d period covered by our study, fetal rabbit lung exhibits significant increases in surfactant phospholipid production and surfactant protein mRNA expression, both in vivo and in vitro $(10,24,38,39)$.

One variable in the various studies addressing the effects of surfactant replacement on surfactant metabolism is that different surfactants, with different compositions, were used. To learn more about the effect of surfactant replacement on the developing lung we chose to study exogenous surfactants that have differing protein and phospholipid composition. Survanta and Curosurf lack SP-A but have differing amounts of several phospholipids, including disat-PC. Survanta also has $<10 \%$ of the SP-B concentration of native surfactant. Exosurf lacks all surfactant proteins and the minor phospholipid components. NARS has a complement of SP-A, SP-B, and SP-C. We found 
that treatment with Survanta enhanced the incorporation of ${ }^{3} \mathrm{H}$-choline and of ${ }^{14} \mathrm{C}$-glycerol into LB disat-PC. Further studies using glycerol as the precursor showed that this was dose-dependent. In a limited number of experiments, we have also observed a similar stimulation of LB disat-PC synthesis using Curosurf (Fiore, Petit, and Nielsen; unpublished data). To test whether increased LB disat-PC was caused by an inhibition of surfactant secretion, we measured the effect of surfactant replacement on surfactant secretion for $24 \mathrm{~h}$ into the culture media, and found no effects.

Neither Exosurf nor NARS had a significant effect on the formation of LB disat-PC. The stimulatory effect of Survanta may be related to changes in precursor pool size, which we could not measure. For example, Survanta is supplemented with fatty acids, including palmitic acid. However, if this were true, then NARS might be expected to also affect the precursor pool and therefore disat-PC synthesis, yet it had the opposite effect on synthesis from Survanta. Surfactant recovered from the alveolar space exhibits multiple forms, including a large aggregate form that exhibits good surface-lowering properties, and a small aggregate form lacking surface-lowering properties [reviewed in Bourbon (43)]. The difference in structure and function between these two forms is thought to be the presence of the surfactant proteins in the large aggregate form (43). Both the Survanta and the NARS in this study are likely composed of mostly large aggregate forms, suggesting the lack of stimulation by NARS may be related to other nonsurfactant components of Survanta, such as tissue factors, growth factors, or cytokines. In a series of recent studies Jobe et al. (44) and Kramer et al. (45) have shown the stimulatory effect of endotoxin on fetal lamb lung surfactant phospholipid and surfactant protein production. To test this possibility we measured endotoxin levels in Survanta and NARS, using the sensitive limulus amebocyte lysate method (measurements performed by Charles River Endosafe, Charleston, SC, U.S.A.). NARS contained 52 endotoxin units per milliliter $(\mathrm{EU} / \mathrm{mL})$ and Survanta contained $36 \mathrm{EU} / \mathrm{mL}$. Considering the volume of culture media and the amount of surfactant administered, cultures were therefore exposed to $0.9-1.5 \mathrm{EU} / \mathrm{mL}$ media in the Survanta group and 4.0-6.0 EU/mL in the NARS group. These levels are several orders of magnitude lower than amniotic fluid endotoxin levels measured $24 \mathrm{~h}$ after administration of $10 \mathrm{mg}$ of endotoxin intraamniotically to the fetal sheep (Ikegami, personal communication).

Others have studied the effects of natural surfactant, Survanta, and Exosurf on cellular functions. Natural surfactant obtained by lung lavage of adult rats and Survanta both inhibited lipopolysaccharide-induced nitric oxide production by alveolar macrophages and reduced nitric oxide synthase enzyme, effects that were not reproduced by disat-PC or SP-A alone, but were induced by SP-B alone (46). The magnitude of the Survanta effect in that study could be titered to the calculated concentration of SP-B in the administered Survanta. Both Survanta and Exosurf down-regulated lung fibroblast proliferation and inhibited induction by IL- 1 of IL- 6 and prostaglandin $\mathrm{E}_{2}$ production (47). The mechanisms involved in this study were not apparent, but could not involve the surfactant proteins as Exosurf lacks these. Thus, biologic effects of different pulmonary surfactants, including those found in this study, result from several potentially different mechanisms. We speculate that the stimulation of disat-PC synthesis in this study by Survanta represents a complex interaction between the lipid and protein components of this preparation on the developing lung, including the possible presence of growth factors or cytokines derived from the lung tissue from which Survanta is prepared.

The effect of surfactant administration on surfactant phospholipid synthesis is only one aspect of its potential effect on surfactant metabolism (48). Exogenous surfactant components may inhibit the production or the function of surfactant proteins, which play an important role in regulating clearance, recycling, and pool size of endogenous surfactant $(49,50)$. The presence or absence of the surfactant proteins SP-A, SP-B, and SP-C in the surfactant replacement mixture might influence endogenous surfactant protein mRNA expression, especially in the developing lung $(29,51,52)$. The effect of different surfactant preparations on endogenous surfactant protein metabolism is also uncertain (53). Our data show no effect of treating with surfactants of different protein compositions on the development of surfactant protein mRNA expression. This indicates that although endogenous surfactant proteins play important roles in the metabolism and function of surfactant, the exogenous application of surfactant material has no important impact on the development of endogenous surfactant protein mRNA expression. These results, taken together with our data on surfactant phospholipid metabolism, suggest differing regulation of surfactant protein and lipid production.

Because we extracted and analyzed phospholipids from LB, we were able to focus on de novo synthesis of surfactant disat-PC, rather than tissue phospholipid. Two different precursors were used that address two separate steps in surfactant disat-PC formation. ${ }^{3} \mathrm{H}$-choline is used by choline phosphate cytidyltransferase, the rate-limiting enzyme in $\mathrm{PC}$ synthesis (1). ${ }^{14} \mathrm{C}$-glycerol is used as the glycerol backbone moiety in the formation of phospholipids. We found a close agreement in the results with these two labels, similar to other studies of the control of fetal lung maturation in organ culture $(38,39,54)$. Although initial studies suggested that NARS may reduce disat-PC synthesis, subsequent studies involving just NARS and controls, using ${ }^{3} \mathrm{H}$-choline as the precursor, did not confirm this. Because of the overall agreement of ${ }^{3} \mathrm{H}$-choline and ${ }^{14} \mathrm{C}$-glycerol incorporation in this and other studies it is unlikely that a different result would have been obtained with ${ }^{14} \mathrm{C}$-glycerol.

\section{CONCLUSIONS}

In conclusion, we found that 3-d exposure to $100 \mathrm{mg} / \mathrm{kg}$ body weight of Survanta, but not Exosurf or NARS, significantly increased the de novo synthesis of surfactant disat-PC. Thus, surfactant replacement therapy is capable of enhancing the maturation of the immature type II cell. Because a major difference between the three surfactants studied is their surfactant apoprotein composition, it is possible that observed effects may have been influenced by the surfactant protein components. However, several other potential components of Survanta, such as the possible presence of tissue cytokines or 
growth factors retained in the Survanta preparation, may also have influenced the response. It is important to note that these studies were performed in an in vitro model of developing rabbit lung; one cannot conclude that clinical use of Survanta will stimulate human lung development in vivo in the same manner. Yet these studies do suggest that surfactant therapies are unlikely to disrupt the normal developmental maturation of surfactant synthesis, and suggest the potential for beneficial effects on lung maturation. Further studies of the mechanisms of enhanced surfactant disat-PC synthesis by exogenous surfactant may contribute to the development of improved surfactant preparations.

Acknowledgments. The authors thank Professor P. Burri for support and reviewing of the manuscript, and Drs. F. Possmeyer and M. Shen for their helpful advice and contributions.

\section{REFERENCES}

1. Rooney SA, Young SL, Mendelson CR 1994 Molecular and cellular processing of lung surfactant. FASEB J 8:957-967

2. Hawgood S 1989 Pulmonary surfactant apoproteins: a review of protein and genomic structure. Am J Physiol 259:L13-L22

3. Baritussio A, Alberti A, Quaglino D, Pettenazzo A, Dalzoppo D, Sartori L, PasqualiRonchetti I 1994 SP-A, SP-B, and SP-C in surfactant subtypes around birth: reexamination of alveolar life cycle of surfactant. Am J Physiol 266:L436-L447

4. Gross I 1990 Regulation of fetal lung maturation. Am J Physiol 259:L337-L344

5. Akinbi HT, Breslin JS, Ikegami M, Iwamoto HS, Clark JC, Whitsett JA, Jobe AH, Weaver TE 1997 Rescue of SP-B knockout mice with a truncated SP-B proprotein: function of the C-terminal propeptide. J Biol Chem 272:9640-9647

6. Jobe A, Ikegami M 1987 Surfactant for the treatment of respiratory distress syndrome. Am Rev Respir Dis 136:1256-1275

7. Soll RF, Hoekstra RE, Fangman JJ, Corbet AJ, Adams JM, James LS, Schulze K, Oh W, Roberts Jr JD, Dorst JP, Kramer SS, Gold AJ, Zola EM, Horbar JD, McAuliffe TL, Lucey JF 1990 Multicenter trial of single-dose modified bovine surfactant extract (Survanta) for prevention of respiratory distress syndrome. Ross Collaborative Surfactant Prevention Study Group. Pediatrics 85:1092-1102

8. Kendig JW, Notter RH, Cox C, Aschner JL, Benn S, Bernstein RM, HendricksMunoz K, Maniscalco WM, Metlay LA, Phelps DL, Sinkin RA, Wood BP, Shapiro DL 1988 Surfactant replacement therapy at birth: final analysis of a clinical trial and comparisons with similar trials. Pediatrics 82:756-762

9. Durham PL, Nanthakumar EJ, Snyder JM 1992 Developmental regulation of surfactant-associated proteins in rabbit fetal lung in vivo. Exp Lung Res 18:775-793

10. Ohashi T, Polk D, Ikegami M, Ueda T, Jobe A 1994 Ontogeny and effects of exogenous surfactant treatment on SP-A, SP-B, and SP-C mRNA expression in rabbit lungs. Am J Physiol 267:L46-L51

11. Jacobs H, Jobe A, Ikegami M, Jones S 1982 Surfactant phosphatidylcholine source, fluxes, and turnover times in 3-day-old, 10-day-old, and adult rabbits. J Biol Chem 257:1805-1810

12. Jacobs HC, Ikegami M, Jobe AH, Berry DD, Jones S 1985 Reutilization of surfactant phosphatidylcholine in adult rabbits. Biochim Biophys Acta 837:77-84

13. Jacobs H, Jobe A, Ikegami M, Conaway D 1983 The significance of reutilization of surfactant phosphatidylcholine. J Biol Chem 258:4159-4165

14. Nielsen HC, Kellogg CK, Doyle CA 1992 Development of fibroblast-type II cell communications in fetal rabbit lung organ culture. Biochim Biophys Acta 1175:95-99

15. Ueda T, Ikegami M 1996 Change in properties of exogenous surfactant in injured rabbit lung. Am J Respir Crit Care Med 153:1844-1849

16. Seidner SR, Jobe AH, Ruffini L, Ikegami M, Pettenazzo A 1989 Recovery of treatment doses of surfactants from the lungs and vascular compartments of mechanically ventilated premature rabbits. Pediatr Res 25:423-428

17. Lowry OH, Rosebrough NJ, Farr AL, Randall RJ 1951 Protein measurements with the Folin phenol reagent. J Biol Chem 193:265-275

18. Nielsen HC 1986 The development of surfactant synthesis in fetal rabbit lung organ culture exhibits a sex dimorphism. Biochim Biophys Acta 883:373-379

19. Bartlett GR 1959 Phosphorus assay in column chromatography. J Biol Chem 234:466-468

20. Torday J, Carson L, Lawson EE 1979 Saturated phosphatidylcholine in amniotic fluid and prediction of the respiratory distress syndrome. N Engl J Med 301:1013-1018

21. Ramadurai SM, Nielsen HC, Chen Y, Hatzis D, Sosenko IRS 1998 Differential effects in vivo of thyroid hormone on the expression of surfactant phospholipid, surfactant protein mRNA and antioxidant enzyme mRNA in fetal rat lung. Exp Lung Res 24:641-657

22. Shen MM, Leder P 1992 Leukemia inhibitory factor is expressed by the preimplantation uterus and selectively blocks primitive ectoderm formation in vitro. Proc Natl Acad Sci USA 89:8240-8244
23. Zar JH 1996 Biostatistical Analysis. Prentice-Hall, Inc, Upper Saddle River, NJ, pp 123-130, 286-301

24. Connelly IH, Hammond GL, Harding PG, Possmayer F 1991 Levels of surfactantassociated protein messenger ribonucleic acids in rabbit lung during perinatal development and after hormonal treatment. Endocrinology 129:2583-2591

25. Rider ED, Ikegami M, Whitsett JA, Hull W, Absolom D, Jobe AH 1993 Treatment responses to surfactants containing natural surfactant proteins in preterm rabbits. Am Rev Respir Dis 147:669-676

26. Rice WR, Ross GF, Singleton FM, Dingle S, Whitsett JA 1987 Surfactant-associated protein inhibits phospholipid secretion from type II cells. J Appl Physiol 63:692-698

27. Miles PR, Wright JR, Bowman L, Castranova V 1983 Incorporation of ${ }^{3} \mathrm{H}$-palmitate into disaturated phosphatidylcholine in alveolar type II cells isolated by centrifugal elutriation. Biochim Biophys Acta 753:107-118

28. Thakur NR, Tesan M, Tyler NE, Bleasdale JE 1986 Altered lipid synthesis in type II pneumonocytes exposed to lung surfactant. Biochem J 240:679-690

29. Wohlford-Lenane CL, Durham PL, Snyder JM 1992 Localization of surfactantassociated protein C mRNA in fetal rabbit lung tissue by in situ hybridization. Am J Respir Cell Mol Biol 6:225-234

30. Gilfillan AM, Chu AJ, Rooney SA 1984 Stimulation of phosphatidylcholine synthesis by exogenous phosphatidylglycerol in primary cultures of type II pneumocytes. Biochim Biophys Acta 794:269-273

31. Pinkerton KE, Lewis J, Mulder AM, Ikegami M, Jobe AH 1993 Surfactant treatment effects on alveolar type II cell morphology in rabbit lungs. J Appl Physiol 74:1240-1247

32. Pettenazzo A, Ikegami M, Seidner S, Jobe A 1988 Clearance of surfactant phosphatidylcholine from adult rabbit lungs. J Appl Physiol 64:120-127

33. Oguchi K, Ikegami M, Jacobs H, Jobe A 1985 Clearance of large amounts of natural surfactants and liposomes of dipalmitoyl phosphatidylcholine from the lungs of rabbits. Exp Lung Res 9:221-235

34. Seidner S, Rider E, Jobe A, Yamada T, Ikegami M 1992 Effects of antenatal thyrotropin-releasing hormone, antenatal corticosteroids, and postnatal ventilation on surfactant mobilization in premature rabbits. Am J Obstet Gynecol 166:1551-1559

35. Woods E, Ohashi T, Polk D, Ikegami M, Ueda T, Jobe AH 1995 Surfactant treatment and ventilation effects on surfactant SP-A, SP-B, and SP-C mRNA levels in preterm lamb lungs. Am J Physiol 269:L209-L214

36. Stewart-DeHaan PJ, Metcalfe IL, Harding PG, Enhorning G, Possmayer F 1980 Effect of birth and surfactant treatment on phospholipid synthesis in the premature rabbit. Biol Neonate 38:238-247

37. Ikegami M, Jobe AH, Yamada T, Priestly A, Ruffini L, Rider E, Seidner S 1989 Surfactant metabolism in surfactant-treated preterm ventilated lambs. J Appl Physiol 67:429-437

38. Snyder JM, Mendelson CR, Johnston JM 1981 The effect of cortisol on rabbit fetal lung maturation in vitro. Dev Biol 85:129-140

39. Mendelson CR, Snyder JM 1985 Effect of cortisol on the synthesis of lamellar body glycerophospholipids in fetal rabbit lung tissue in vitro. Biochim Biophys Acta 834:85-94

40. Klein JM, McCarthy TA, Dagle JM, Snyder JM 2000 Antisense inhibition of epidermal growth factor receptor decreases expression of human surfactant protein A. Am J Respir Cell Mol Biol 22:676-684

41. Torday JS, Zinman HM, Nielsen HC 1986 Glucocorticoid regulation of DNA, protein and surfactant phospholipid in developing lung: temporal relationship between growth and development. Dev Pharmacol Ther 9:124-131

42. Rooney SA, Gobran LI, Marino PA, Maniscalco WM, Gross I 1979 Effects of betamethasone on phospholipid content, composition and biosynthesis in fetal rabbit lung. Biochim Biophys Acta 572:64-76

43. Bourbon JR 1991 Secretion, alveolar processing, and turnover of pulmonary surfactant. In: Bourbon JR (ed) Pulmonary Surfactant: Biochemical, Functional, Regulatory, and Clinical Concepts. CRC Press, Boca Raton, FL, pp $143-183$

44. Jobe AH, Newnham JP, Willet K, Moss TJ, Ervin MG, Padbury JF, Sly PD, Ikegami M 2000 Endotoxin induced lung maturation in preterm lambs is not mediated by cortisol. Am J Respir Crit Care Med 162:1656-1661

45. Kramer BW, Moss T, Willet K, Newnham J, Sly P, Kallapur SG, Ikegami M, Jobe A 2001 Dose and time response after intra-amniotic endotoxin in preterm lambs. Am J Respir Crit Care Med 164:982-988

46. Miles PR, Bowman L, Rao KMK, Baatz JE, Huffman L 1999 Pulmonary surfactant inhibits LPS-induced nitric oxide production by alveolar macrophages. Am J Physiol 276:L186-L196

47. Thomassen MJ, Antal JM, Barna BP, Divis LT, Meeker DP, Wiedemann HP 1996 Surfactant downregulates synthesis of DNA and inflammatory mediators in normal human lung fibroblasts. Am J Physiol 270:L159-L163

48. Jobe AH, Ikegami M, Seidner SR, Pettenazzo A, Ruffini L 1989 Surfactant phosphatidylcholine metabolism and surfactant function in preterm, ventilated lambs. Am Rev Respir Dis 139:352-359

49. Rider ED, Ikegami M, Jobe AH 1992 Localization of alveolar surfactant clearance in rabbit lung cells. Am J Physiol 263:L201-L209

50. Wright JR 1990 Clearance and recycling of pulmonary surfactant. Am J Physiol 259:L1-L12

51. Beers MF, Fisher AB 1992 Surfactant protein C: a review of its unique properties and metabolism. Am J Physiol 263:L151-L160

52. Haagsman HP, White RT, Schilling J, Lau K, Benson BJ, Golden J, Hawgood S, Clements JA 1989 Studies of the structure of lung surfactant protein SP-A. Am J Physiol 257:L421-L429

53. Ikegami M, Agata Y, Elkady T, Kallman M, Berry D, Jobe A 1987 Comparison of four surfactants: in vitro surface properties and responses of preterm lambs to treatment at birth. Pediatrics 79:38-46

54. Snyder JM, Johnston JM, Mendelson CR 1981 Differentiation of type II cells of human fetal lung in vitro. Cell Tissue Res 220:17-25 